\title{
Cognitive Modeling Concepts of Sustainable Development of Society
}

\section{Koncepcje kognitywnego modelowania zrównoważonego rozwoju społeczeństwa}

\author{
Elina Boichenko ${ }^{\star 1}$, Nataly Martynovych ${ }^{\star 2}$, Iryna Shevchenko** \\ *Institute of Economic and Legal Studies of the National Academy of Sciences of Ukraine, \\ Department of Problems of Inter-regional Cooperation Issues, \\ 60 Shevchenko blvd., zip code: 01032, Kyiv, Ukraine \\ E-mail: economicaukraina2017@gmail.com \\ ${ }^{1}$ ORCID: 0000-0003-1121-7160, ${ }^{2}$ ORCID: 0000-0001-9884-6052 \\ **Simon Kuznets Kharkiv National University of Economics, \\ 9-A Nauki Ave., zip code: 61166, Kharkiv, Ukraine \\ E-mail: irina_shev4enko@ukr.net,ORCID:000-0001-8188-3551
}

\begin{abstract}
In the context of rapid scientific and technological progress, which is the result of the development of science and technology and the process of accumulation and creation of new knowledge, fundamental and applied scientific research, information and technological changes are taking place. As a result, scientific-technological progress arose new forms and methods of organization of production, introduced a new technology, automated production processes, accelerating rate digitalization of all spheres of society, etc. The information society creates prerequisites for the diversification of the structure of production and consumption, thereby changing the needs of society, encouraging the producer to create more and more new goods and services. However, along with the development of advanced technologies, there is the rapid destruction of nature and environmental pollution caused by the consequences of human industrial activity. The article substantiates the socio-ecological aspects of sustainable development on the basis of cognitive modeling, as well as suggests specific measures that contribute to the implementation of certain goals of the International strategy for sustainable development 2030. It is proved that the functioning of the technogenic system leads to the emergence of technogenic risks, the existence of which confirms the presence of a causal relationship between the technogenic load on the environment and the state of public health. The necessity of diagnostics of ecological and safe development of the population, which is designed to identify the selected parameters of the technogenic danger in the changing socio-economic reality, is justified.
\end{abstract}

Key words: ecology, technogenic risks, technogenic system, economy, society, business, sustainable development, cognitive modeling

\section{Streszczenie}

W czasie szybkiego postępu naukowo-technicznego, będącego wynikiem rozwoju nauki i techniki oraz procesu gromadzenia i tworzenia nowej wiedzy, prowadzone są badania naukowe, zachodzą zmiany informacyjne i technologiczne. Postęp naukowo-techniczny zaowocował nowymi formami i metodami organizacji produkcji, wprowadził nową technologię, zautomatyzował procesy produkcyjne, przyspieszył tempo cyfryzacji wszystkich sfer społeczeństwa itp. Społeczeństwo informacyjne stwarza warunki do dywersyfikacji struktury produkcji i konsumpcji, zmieniając tym samym potrzeby społeczeństwa, zachęcając producentów do tworzenia coraz większej ilości nowych dóbr i usług. Jednak wraz z rozwojem zaawansowanych technologii następuje gwałtowne niszczenie przyrody, rośnie także zanieczyszczenie środowiska. Artykuł konretyzuje społeczno-ekologiczne aspekty zrównoważonego rozwoju w oparciu o modelowanie poznawcze, a także sugeruje konkretne działania, które mogą 
przyczynić się do realizacji określonych celów Międzynarodowej strategii zrównoważonego rozwoju 2030. Udowodniono, że technologie technogeniczne prowadzą do powstania zagrożeń, których istnienie potwierdza istnienie związku przyczynowego między obciążeniem technogenicznym środowiska a stanem zdrowia publicznego. Uzasadniona jest konieczność diagnostyki ekologicznego i bezpiecznego rozwoju populacji, mającej na celu identyfikację wybranych parametrów zagrożenia technogenicznego w zmieniającej się rzeczywistości społeczno-gospodarczej.

Słowa kluczowe: ekologia, ryzyka technogeniczne, system technogeniczny, ekonomia, społeczeństwo, biznes, zrównoważony rozwój, modelowanie kognitywne

\section{Introduction}

Modern conditions of development are characterized by constant transformations in science, technology, economy, business, and society, which was the result of the beginning of the fourth industrial revolution. This fact can be argued by the thesis of the experts of the WEF (World Economic Forum) The Taoist Forum, which in January 2017 stated is underground, which means the fourth industrial revolution is in full swing. The head of this non-governmental organization, Klaus Schwab (2016), spoke about its offensive back in 2016. Previous revolutions were marked by several events, thanks to which, on the one hand, modern society crossed the barrier of the fourth round of development, and on the other, caused enormous damage to the environment. So the result of the first industrial revolution (1778-1869) was the invention of mechanisms that replace manual labor, which changed the consciousness of society and contributed to the transition to the next stage of development. The electrification and production of Bessemer steel contributed to the improvement of technology (the second industrial revolution of 1870-1914), and programming, the creation of industrial robots, automation of production, and rapid economic growth after the 1970s led to the emergence of mobile phones, personal computers (the third industrial revolution of 1948-2010), without which modern society cannot imagine its life. Thus, the growing needs of the consumer society are an incentive for the development of products to meet these very needs at any cost. So there is a problem in the irrational use of natural resources, the disposal of already produced goods, etc. In this connection, the problem of the formation of sustainable development is gaining more and more relevance, which over the past twenty years has attracted the attention of scientists, businessmen, and society as a whole, which led to the choice of the direction of research. The article focuses on the conceptualization of the theoretical, methodological, and applied apparatus that contributes to the implementation of the goals of the international strategy for sustainable development Transforming our World: the agenda for sustainable development for the period up to 2030 .

The purpose of this study is to provide cognitive modeling of the concept of sustainable development of society.

\section{Methodology}

The methodological basis of the research is a set of methods of scientific knowledge, general scientific and special research methods. The theoretical basis of the author's statements regarding the concepts of technogenic system and technogenic risks is the fundamental research of scientists in the field of economic theory, regional economics and sustainable development of territories, sociology, strategic management of socio-economic development of regions. The main conclusions of the authors regarding sustainable development are based on the research of Peter Senge, who developed ideas about the rational use of resources, arguing that it is our common duty (Senge, 2008). The basis for the conceptualization of sustainable development of society was formed by the works of Artur Pawłowski (Pawłowski, 2015). In particular, he discusses the general and specific principles of sustainable development that contribute to solving the methodological problem of sustainable development. The results of research by A. Skowroński (Skowroński, 2003) and B. Sienenhuner (Sienenhuner, 2000), whose works raise questions about new concepts and values of sustainable development, contributed to the idea of transformation in the structure of production, as a result of which the basic scheme of the functioning of the law of the elevation of needs was developed.

Works by V. Gradovsky (Gradovsky, 2003), D. Zerkalov, K. Tkachuk (D. Zerkalov, K. Tkachuk, 2011), N. Blinova, V. Mokhonko (Blinova, Mokhonko, 2009) which are devoted to solving several environmental problems, namely: V. Gradovsky studied the impact of ecology on human health; D. Zerkalov, K. Tkachuk, who considered engineering ecology, proposed methodological support for monitoring the state of the environment; in the studies of N. Blinova, V. Mokhonko, the issues of environmental standardization and certification are considered. Theoretical and methodological developments I. Nujna, O. Nesterova, O. Pozharitskii (Nujna, 2012), (Nesterova, Pozharitskaya, 2018) They allowed us to form conceptual provisions on the diagnosis of ecological and safe development of the population based on the assessment of well-being from the perspective of sustainable human development, as well as to establish that in modern science there is no single methodology for determining the assessment of 


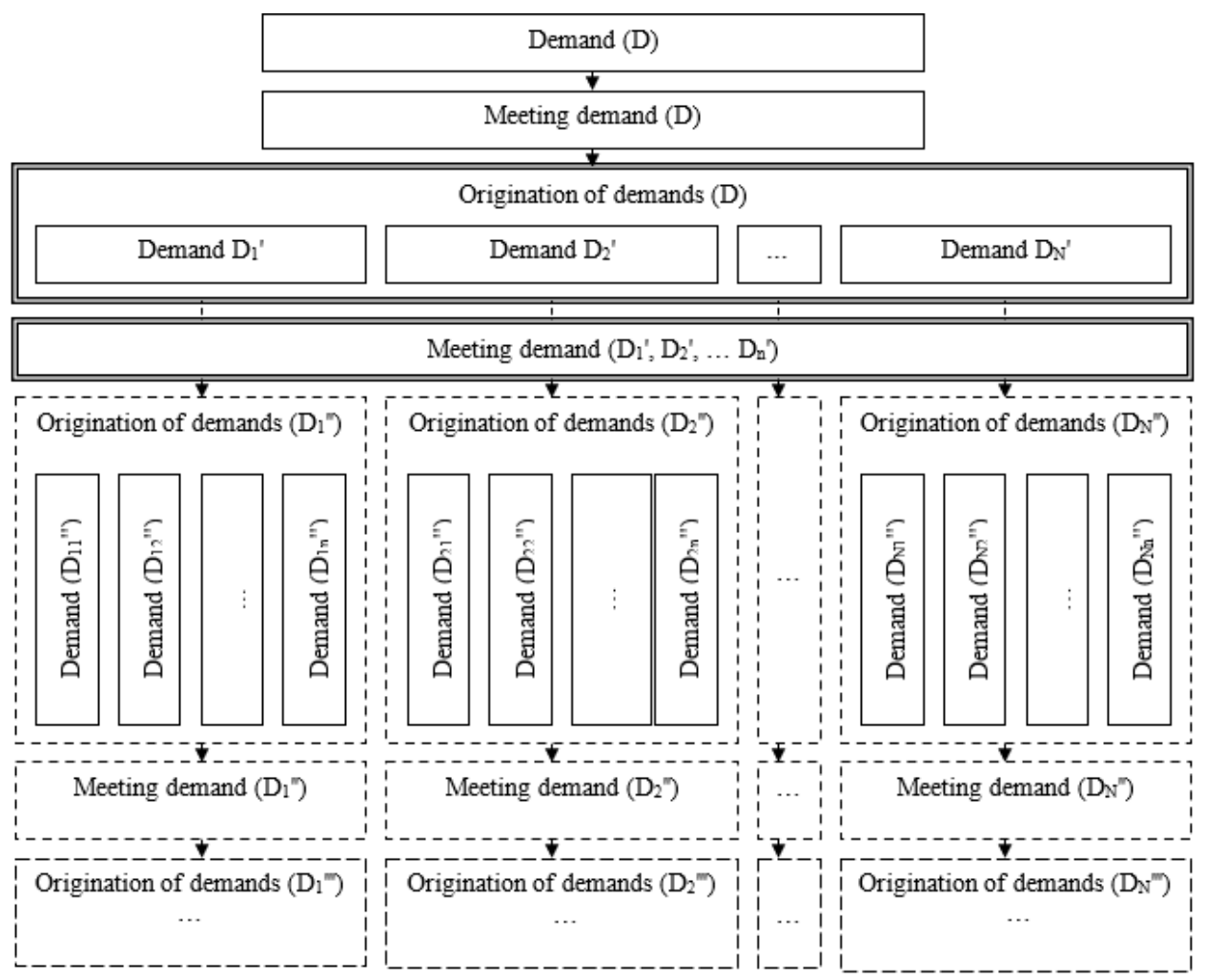

Figure 1. Schematic diagram of the functioning of the law of the elevation of needs, compiled by the authors

man-made hazards, so this problem requires additional scientific analysis and study.

Based on the analysis of scientific studies by F. Machlup (Machlup, 2000), Y. Masuda (Masuda, 1981), M. Dvornik (Dvornik, 2013), which are devoted to the formation and development of the information society, conclusions were made about the impact of information on the life of society. However, despite the relative development of the problems and prospects of sustainable development, certain aspects of this multi-faceted sphere remain controversial, sometimes contradictory, which require further study.

The applied basis of the research is based on the Brundtland Report, or as it is also commonly called the report of the World Commission on Environment and Development Our Common Future, which was published in October 1987 by the United Nations through Oxford University Press and is the basis of the modern international strategy for sustainable development Transforming our world: the 2030 Agenda for Sustainable Development (Report, 1987).

\section{Findings and Discussion}

Goal 12 Ensuring the transition to rational consumption and production models. The solution to the stated problem involves clarifying such concepts as the technogenic system and technogenic risks, as well as their impact on the state of the environment.
The functioning of the technogenic system of the territory is accompanied by the emergence of technogenic risks. It should be noted that when considering technogenic risks, the emphasis is placed on their real and potential impact on the environment.

In modern science, certain methods of assessing man-made risks have already been formed: first, it is the definition of economic losses, which are defined as the loss of material values; second, it is environmental damage, which manifests itself in the form of negative consequences of environmental impact and; third, it is social losses, which are determined by human casualties, namely, these are losses caused by accidents that led to the loss of temporary disability, disability, deaths, occupational diseases, etc.

Economic science has proved that the satisfaction of some needs of society leads to the emergence of many others, the satisfaction of which will be directed to the efforts of their producer. This postulate is based on a pattern confirmed by the long history of mankind, which is the law of the exaltation of needs. This is also evidenced by the simple fact that every ten years the number of types of consumer goods and services increases more than twice, while the volume of their consumption increases (Skowroński, 2003), (Sienenhuner, 2000). In the conditions of the development of society, there is a modification of needs, the disappearance of some, and the emergence of others. In turn, this causes changes in the structure of production and determines the development of the technogenic system. Schematically, the effect of this law can be represented in the form of Figure 1. 


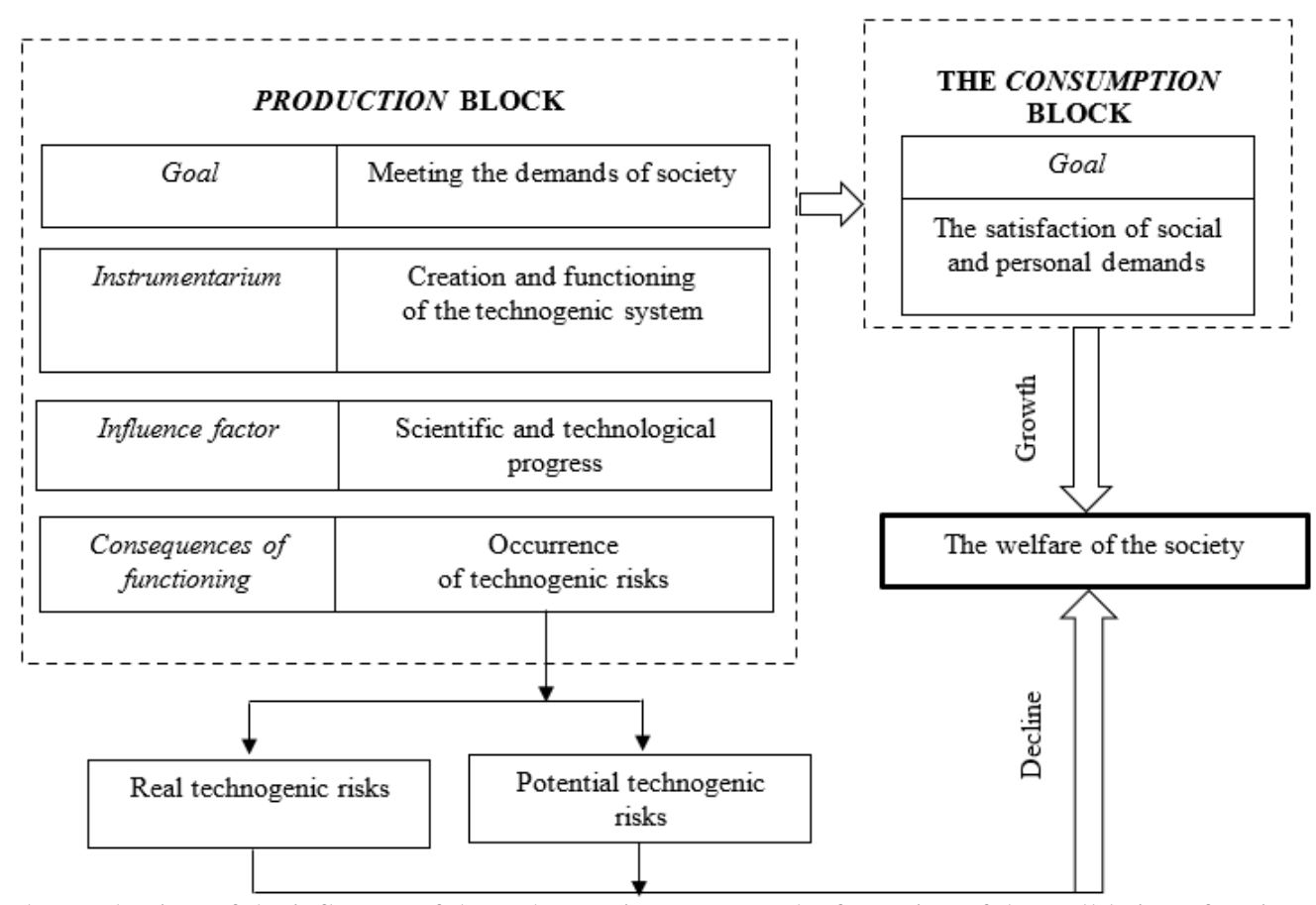

Figure 2. The mechanism of the influence of the technogenic system on the formation of the well-being of society (Compiled by the author based on a summary of scientific publications, based on Pawłowski, 2015

The interpretation proposed in the figure is related to the implementation of Goal 13 Taking urgent action to combat climate change and its consequences of the international strategy for sustainable development Transforming our World: the 2030 Agenda for sustainable development. It allows you to display the transformation of needs in a concise form and focus the actions of society on solving a specific problem, the name of which is irrational consumption. However, such a vector of development also has a negative impact. First of all, this is a global problem of environmental pollution caused by industrial technological processes. On the other hand, this is the occurrence of accidents and emergencies due to errors and non-compliance with production processes; exceeding the critical level of wear of the equipment used, buildings, and structures; non-compliance with the technology of storage and transportation of fuels and lubricants and the operation of military facilities, and so on.

Under the technogenic system, the authors of the article understand a set of interrelated technical, technological, and social objects created by man in the cycle of production and economic activity under the influence of scientific and technological progress, which provide an increase in the rate of intensification of production and economic activity and social changes in society.

The development of the technogenic system of a territory (state, region) is inherently contradictory. On the one hand, an important condition for the development of the territory is scientific and technological progress. The positive effect of such development is reflected in the creation of an enabling environment to meet the diverse and ever-increasing needs of society. On the other hand, the opposite of such development is the pollution of the environment and the destruction of the natural landscape. So, as a result of the vital activity of society, there is such a change in the quality of the natural environment that leads to the undermining of the natural conditions of human existence. The consequences of these changes in the future may be the destruction of the biosphere.

Thus, the functioning of the technogenic system leads to the emergence of technogenic risks, the existence of which confirms the existence of a causal relationship between the technogenic load on the environment and the reproduction of the living conditions of society (Fig. 2).

Theoretical and methodological understanding of the mechanism of the influence of man-made systems on the formation of the welfare of society helps to extend the scientific basis based on which develop measures applied to ensure the realization of Goal 13 take urgent action to combat climate change and its impacts; Goals 14, Conserve and manage the oceans, seas and marine resources for sustainable development and Goals 15, Protect and restore terrestrial ecosystems and promote sustainable use, manage forests, combat desertification, halt and reverse land degradation and halt biodiversity loss of the international strategy for sustainable development, Transforming our World: the 2030 Agenda for Sustainable Development (Development program of the Organization of the United Nations, 2020).

It should be noted that technogenic risks in this study are understood as the probability of occurrence of undesirable events as a result of human production 


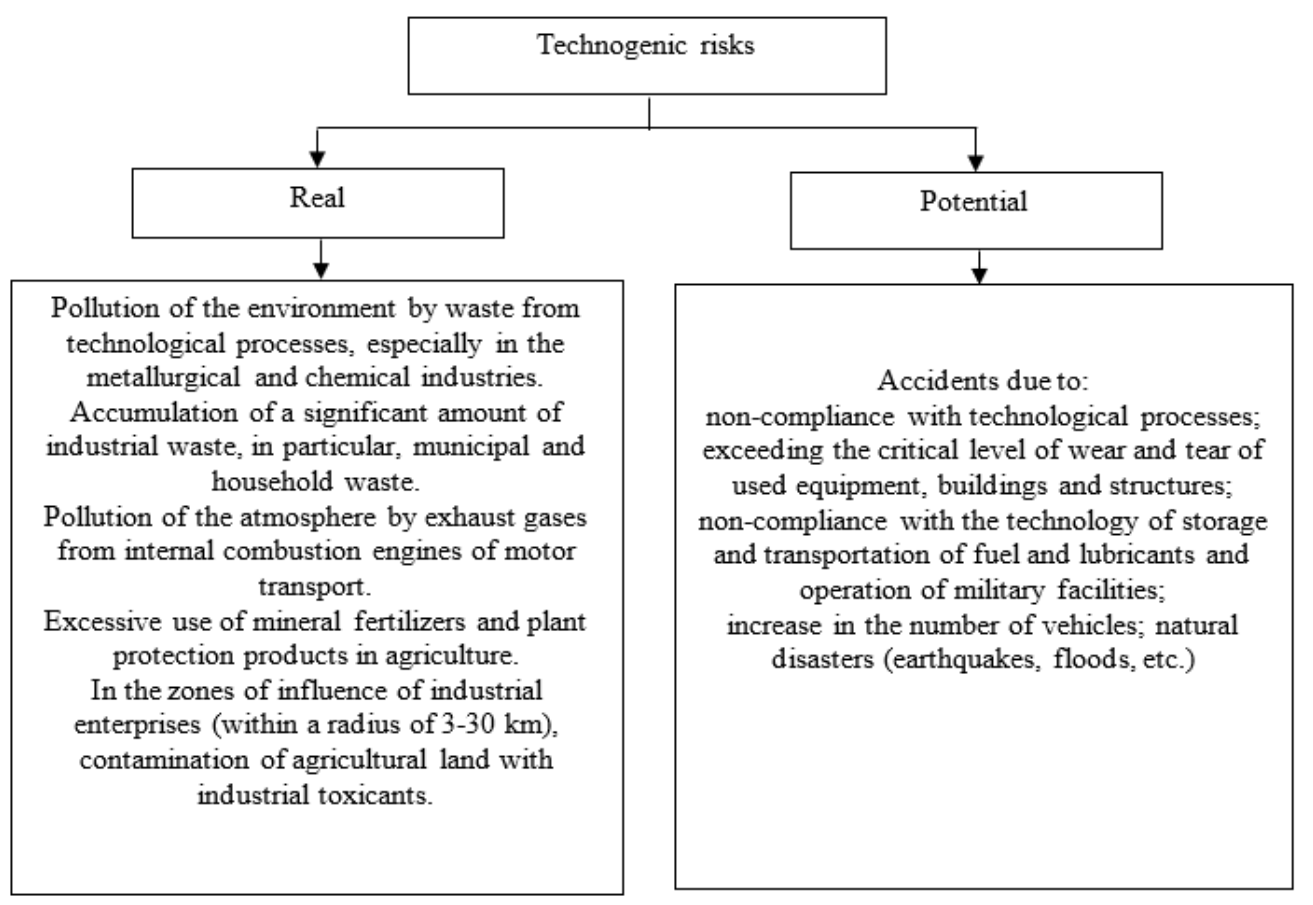

Figure 3. Risks generated by the functioning of the technogenic system (Compiled by the author based on the generalization of scientific results, based on: Gradovsky V., 2003; Zerkalov D., Tkachuk K., 2011; Blinova N., Mokhonko V., 2009

and economic activity in the form of a real and potential danger of obtaining damaging effects on humans and the environment (Fig. 3). Consideration of technogenic risks (real and potential) is associated with the implementation of Goal 11 Ensuring openness, security, resilience and environmental sustainability of cities and human settlements, since the consequences of such impacts can be not only negative, but also catastrophic, and negatively affect the health of people, their livelihoods, change (in the worse way) their well-being, and can also be disastrous for the ecology of the territory.

The effect of real technogenic risks is manifested in the pollution of the environment by waste from technological processes, especially in the metallurgical and chemical industries; the accumulation of a significant amount of industrial waste, as well as municipal and household waste; air pollution by exhaust gases from internal combustion engines of motor transport; excessive use of mineral fertilizers and plant protection products in agriculture; contamination of agricultural land with industrial toxicants within a radius of $3-30 \mathrm{~km}$. zones of influence of industrial enterprises, etc.

Goal 13 Take urgent action to address climate change and its impacts. If a wide range of technical measures and behavioral changes are applied, it is still possible to keep the increase in global average temperature at 2 degrees Celsius higher than before the advent of the era of industrialization (Development program of the Organization of the United Nations, 2020). The impact of potential technogenic risks is manifested in the occurrence of accidents due to non-compliance with technological processes; ex- ceeding the critical level of wear and tear of used equipment, buildings, and structures; non-compliance with the technology of storage and transportation of fuel and lubricants, and operation of military facilities; an increase in the number of vehicles, etc.; natural disasters (earthquakes, floods, etc.).

Environmental pollution as a result of human production activities, man-made accidents, the consequences of which can be catastrophic, negatively affect both people's health and can affect their material well-being. An example of the largest man-made disaster in the history of mankind is the accident at the fourth power unit of the Chernobyl nuclear power plant, which occurred on April 26, 1986, in the former USSR. It not only led to the radioactive contamination of vast territories and the exposure of millions of people, significant material damage but also caused moral damage to society. The result is a ninepoint earthquake and tsunami on 11 March 2011 in Japan at Fukushima was the largest nuclear disaster, which killed more than 25 thousand people. This accident caused the radiation threat on a global scale. The consequences of the disaster are still being eliminated (Find out everything, 2020).

According to experts, the explosion on the Deepwater Horizon drilling platform that occurred in 2010 (Gulf of Mexico) was bound to happen and was just waiting for its moment. As a result of the incident, about 5 million barrels of oil fell into the water, and the resulting oil slick reached an area of 75 thousand square kilometers, which was about $5 \%$ of the area of the entire Gulf of Mexico. According to experts, this release cannot be considered a disaster in the traditional sense. This is one of those accidents 
Table 1. Assessment of the well-being of society in the context of its sustainable development, Compiled by the authors on the basis of a summary of the results of the study Nyukhnya 2012; Nesterova, Pozharnitskaya 2018

\begin{tabular}{|c|c|c|}
\hline Economic block & Social Block & Environmental block \\
\hline \multicolumn{3}{|c|}{ Direction of research } \\
\hline $\begin{array}{l}\text { Condition of development of the } \\
\text { country's economy }\end{array}$ & Living conditions of the society & Environmental condition \\
\hline \multicolumn{3}{|c|}{ Research indicators } \\
\hline $\begin{array}{l}\text { GDP per capita; the volume of in- } \\
\text { dustrial production; } \\
\text { consumer price index; government } \\
\text { debt (\%of GDP); } \\
\text { gross domestic savings; } \\
\text { GDP deflator; } \\
\text { purchasing power parity; } \\
\text { the volume of exports/imports of } \\
\text { high-tech products (\%of GDP); in- } \\
\text { come and expenses of the popula- } \\
\text { tion; } \\
\text { personal consumer spending and } \\
\text { other }\end{array}$ & $\begin{array}{l}\text { Average life expectancy at birth; } \\
\text { Gini coefficient; } \\
\text { government spending on education (as a \% of } \\
\text { GDP); government spending on health (as a } \\
\% \text { of GDP); } \\
\text { number of Internet users (per } 100 \text { people); } \\
\text { the crime rate, and others }\end{array}$ & $\begin{array}{l}\text { The concentration of pollutants in the } \\
\text { atmosphere; } \\
\text { the concentration of pollutants in water; } \\
\text { the concentration of pollutants in the } \\
\text { soil; } \\
\text { indicators of global climate change; } \\
\text { the number of natural resources and } \\
\text { others. }\end{array}$ \\
\hline \multicolumn{3}{|c|}{ Research instrumentarium } \\
\hline $\begin{array}{l}\text { Methods of quantitative and quali- } \\
\text { tative assessment of the state of the } \\
\text { economic system and its elements }\end{array}$ & $\begin{array}{l}\text { Methods for recognizing and establishing the } \\
\text { level of social well-being and social health of } \\
\text { the society } \\
\text { Assessment of the state of social infrastruc- } \\
\text { ture } \\
\text { Determination of the reference or normative } \\
\text { state of a social object; } \\
\text { the ratio of the reference and real state of a } \\
\text { social object; } \\
\text { sociological research; surveys on various so- } \\
\text { cial problems of individual target groups and } \\
\text { categories of citizens }\end{array}$ & $\begin{array}{l}\text { Methods of studying the state of natural } \\
\text { complexes and their components based } \\
\text { on the data of biological indication and } \\
\text { analysis of indicators of specialized test } \\
\text { systems, monitoring, environmental as- } \\
\text { sessment, and audit }\end{array}$ \\
\hline \multicolumn{3}{|c|}{ The result of the study } \\
\hline $\begin{array}{l}\text { Comprehensive identification of } \\
\text { problems, additional reserves for } \\
\text { the development of the state, re- } \\
\text { gion, enterprise definition of } \\
\text { measures to neutralize the negative } \\
\text { impact }\end{array}$ & $\begin{array}{l}\text { Establishing the level of social well-being } \\
\text { and public health of the society } \\
\text { Determination of social motives and reasons } \\
\text { for the behavior of an individual, group, and } \\
\text { society } \\
\text { Recognition of social pathologies and prob- } \\
\text { lems of public life }\end{array}$ & $\begin{array}{l}\text { Establishing the existing level of an- } \\
\text { thropogenic pressure on natural re- } \\
\text { sources and ecosystems } \\
\text { Assessment of the ecological state of } \\
\text { natural objects and identification of the } \\
\text { consequences of man-made load on the } \\
\text { biosphere }\end{array}$ \\
\hline
\end{tabular}

that could have been completely prevented (Popular Mechanics, 2020).

As a result of a leak (explosion) of toxic methyl isocyanate at a chemical plant for the production of pesticides in the Indian city of Bhopal in early December 1984, a man-made disaster occurred. The release of 27 tons of toxic gas led to the death of more than 20 thousand and injured up to 600 thousand people. The water and the area of the city and surrounding areas remain contaminated to this day (Popular Mechanics, 2020). And this is only the smallest part of the listed man-made disasters.

Every year in the world there are disasters caused by human production activities, as a result, death of people, destruction of infrastructure, and/or environmental disaster. Of course, the scale of these accidents is different, there are local or large-scale, with significant material losses or minor, etc. But the essence of these events (the onset of man-made disasters) is manifested in the postulate that it is caused by human production activity.
In modern science, certain methods of assessing man-made risks have been formed (Nyukhnya, 2012; Nesterova, Pozharnitskaya, 2018):

Firstly, this is the definition of economic losses, from the loss of material values as a result of a man-made accident;

Secondly, it is the environmental damage caused by the negative consequences of a man-made accident; Thirdly, these are social losses that are assessed by a person, namely, these are losses caused by manmade accidents that led to the loss of temporary disability, disability, the occurrence of occupational diseases, and the like.

The negative consequences of the impact of manmade risks include a decrease in the well-being of society (human).

It should be noted that the assessment of the wellbeing of a society in the context of its sustainable development is based on the relationship and interdependence of the following blocks - economic, social, and environmental (Table 1). 
The economic component. In the economic life of society, the impact of man-made risks can manifest itself in the deterioration of a person's financial situation. Namely, the destruction of the infrastructure of the territory; material damage in the event of disability as a result of occupational injuries, occupational diseases caused by harmful working conditions, disability and death associated with the production, and the like.

The social component. In social life is the influence is more than the maximum concentration of harmful substances, which is the increase in the incidence of, and mortality from such diseases. It should be noted that along with material and social well-being, the most valuable for a person is the state of his health. Thus, almost all scientists in the world consider such an indicator as life expectancy at birth, which reflects the state of public health and longevity, as one of the main indicators that characterize the quality and standard of living, the well-being of society, and human development. Therefore, in this study, the authors focus on the impact of the state of the natural environment on human health (Senge, Peter, 2008; Machlup, F. 2000; Masuda, 1981).

Environmental component. The state of the natural environment is one of the most important factors affecting human health. According to the definition of the World Health Organization, the main factors affecting the health of the population are lifestyle, the state of the environment, biological and medical (Figure 4).

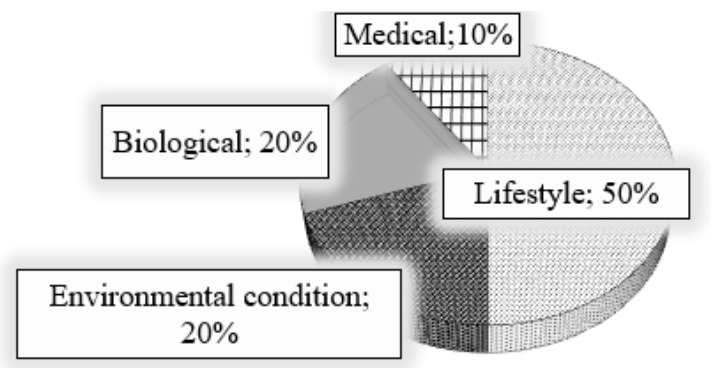

Figure 4. The main factors influencing the health status of the population, Compiled by the author according to the World Health Organization, 2020

According to scientists of the IEPI NAS (Institute of Industrial Economics of the National Academy of Sciences of Ukraine), there is a positive correlation between morbidity and emissions of harmful substances into the atmospheric air (Institute of Economics of Promislovosti, Soldak, 2020).

The same point of view is shared by scientists of the Institute of Economic and Legal Studies of the National Academy of Sciences of Ukraine V. Vasilenko, A. Blagodarny, E. Boychenko. Thus, as a result of the conducted studies, it is proved that the increase in morbidity occurs with an increase in emissions of harmful substances into the atmosphere, soil, and water. Consequently, the constant impact on the state of health of the negative consequences of the functioning of the technogenic system accelerates the accumulation of pathological changes in the human body, contributes to the emergence and development of malignant neoplasms, significantly increases the risks of cancer and deaths from them. Such an analysis is possible based on the relevant indicators of the state of not only the ecological situation but also the technogenic danger of the territory (Vasilenko, Blagodarny, Boychenko, 2012).

The legal aspect. To solve the problems of environmental pollution, the international community has developed and implemented international environmental standards. The decision to develop these standards (ISO 14000) was the result of the Uruguay negotiations on the World Trade Deal and the Summit on Environment and Development in Rio de Janeiro in 1992. These standards define the methods of creating and ensuring the functioning of environmental management systems in enterprises, organizations, requirements for such systems, requirements for environmental audit, etc. (Zerkalov, Tkachuk, 2011).

The functioning of the environmental management system is aimed at greening all spheres of social activity, achieving and maintaining the necessary level of public health and life of the population, the state of the environment, and harmonizing the relationship between society and nature. Environmental management is based on the biotic principles of harmonization of life activity and sustainable development of society. Continuous improvement of the process of greening is one of the conditions of the international and European systems of standardization of environmental management (Blinova, Mokhonko, 2009).

In Ukraine, an environmental policy is also implemented at the state level, the main purpose of which is to protect the natural environment, rational use of natural resources, and ensure the environmental safety of society as an integral condition for sustainable economic and social development. (Official Portal of the Verkhovna Rada of Ukraine, 2020).

\section{Conclusion}

Thus, the article takes measures to solve the theoretical, methodological, and applied aspects of sustainable development based on cognitive modeling. The dependence of the emergence of new, previously non-existent needs on the appearance of new, previously non-existent goods and services is established. An explanation of irrational use of resources of mankind, the essence of which is not in the growing and changing human needs, and growth needs that are not subject to the natural laws of nature, therefore, concluded the formation of the new society wasteful consumption. It is proved that the functioning of the technogenic system leads to the emergence of technogenic risks, the existence of which confirms the presence of a causal relationship between the tech- 
nogenic load on the environment and the state of public health.

Based on the above, the article offers a theoretical, methodological, and applied justification of the conceptual provisions of sustainable development that contribute to the implementation of the goals of the international strategy for sustainable development Transforming our world: The Agenda for Sustainable Development for the period up to 2030. In particular, the grouping of technogenic risks (real and potential) contributes to the implementation of Goal 11 Ensuring openness, security, resilience and environmental sustainability of cities and human settlements.

The author proposes a mechanism of the influence of man-made systems on the formation of the welfare of society helps to extend the scientific basis on which basis within the framework of the implementation of the sustainable development strategy of Ukraine until 2030, develop measures applied to ensure the implementation of strategic and operational goals. In particular, the implementation of Strategic Goal 5 Ensuring the transition to balanced consumption and production models, sustainable management of natural resources and strengthening the response to climate change within the Ukrainian regions contributes to the implementation of Goal 12 Ensuring the transition to rational consumption and production models and Goal 13 Taking urgent measures to combat climate change and its consequences of the international strategy for sustainable development Transforming Our World: the 2030 Agenda for Sustainable Development.

The realization of the Strategic goal 6 Conservation of terrestrial and marine ecosystems and promote sustainable use of their resources, provides an implementation of Goal 14 conserve and sustainably use the oceans, seas and marine resources for sustainable development and Goal 15 Protect and restore terrestrial ecosystems and promoting their rational use, forest management, combating desertification, Halting and reversing land degradation and halting the loss of biodiversity in the international strategy for sustainable development, Transforming Our World: the 2030 Agenda for Sustainable Development.

\section{References}

1. BLINOVA N., MOKHONKO V., 2009, Environmental standardization and certification, Luhansk.

2. Development program of the Organization of the United Nations, https://www.ua.undp.org/content/ ukraine/uk/home/ourwork/sdg-overview.html (21.02.2021).

3. DVORNIK M., 2013, Essence and problems of information society development in Ukraine, Sustainable development of the economy, 4: 75-79.

4. Find out everything, 2020, https://uznayvse.ru/ interesting-facts/samiye-strashniye-tehnogenniyekatastrofi.html (20.12.2020).
5. GRADOVSKY V., 2003, The Influence of the environmental situation on the state of human health in Zhytomyr region, Ecological bulletin, 9 (10): 22-24.

6. Institute of Industrial Economics, 2021, https://us02web.zoom.us/rec/share/6yrR5sV8mK 6AIF81lqR2a2_4Ei_bnaLPFlo7H7SyPNcKOJzU Hdg_29wqkWcaRn0.6ito5apimJfWYrc (7.02.2021).

7. MACHLUP F., 2000, Production and Distribution of Knowledge in the United States, NOP, Princenton.

8. MASUDA Y., 1981, The Information Society as Post-Industrial Society: World Future Society, Transaction Publishers, Tokyo.

9. NESTEROVA O., POZHARNITSKAYA O., 2018, Assessing well-being from the perspective of sustainable human development: the possibilities of international indices, Issues of innovative economy, 8 (3): 335-347.

10. NYUKHNYA I., 2012, The system of socioeconomic indicators for assessing the level of public welfare, Socio-economic phenomena and processes, 12 (46): 245-251.

11. Official portal of the Verkhovna Rada of Ukraine, 2021, http://zakon4.rada.gov.ua/laws/show/126412. (16.01.2021).

12. PAWŁOWSKI A., 2015, Zasada, czy zasady, zrównoważonego rozwoju? Wschodni rocznik humanistyczny, 11: 85-96.

13. Popular mechanics, 2020, https://www.popmech. $\mathrm{ru} /$ technologies/10977-kak-vse-eto-sluchilos-mek sikanskiy-zaliv/ (11.12.2020).

14. Report World Commission on Environment and Development 'Our Common Future' https://www. un.org/ru/ga/pdf/brundtland.pdf (21.02.2021).

15. SCHWAB K., 2016, The Fourth Industrial Revolution, Eksmo, New York.

16. SENGE P. M., SMITH B., SCHLEY S., LAURE J., KRUSCHWITZ N., 2008, The Necessary Revolution: How Individuals and Organizations Are Working Together to Create a Sustainable World, 2st ed., Crown Business, New York.

17. SIENENHUNER B., 2000, Homo sustinens Towards a New Conception of Humans for the Science of Sustainability, Ecological Economics, 32: $15-25$

18. Skowroński, A. 2003, Wartości ekologiczne dla zrównoważonego rozwoju, Filozoficzne $i$ społeczne uwarunkowania zrównoważonego rozwoju, ed. Pawłowski A., Komitet Inżynierii Środowiska PAN, Lublin, 16: 25-32.

19. SOLDAK M., 2020, Industrial ecosystems and digitalization in the context of sustainable development, Industrial Economics, 4 (92): 3864.

20. VASILENKO V., BLAGODARNY A., BOYCHENKO E., 2012, Diagnostics of regional development: types, approaches, techniques, ed. Vasilenko V., National Academy of Sciences of Ukraine Institute of Economic and Legal Sciences, South-East, Donetsk: 558.

21. World Health Organization, 2020, The top 10 causes of death, https://www.who.int/ru/newsroom/fact-sheets/detail/the-top-10-causes-ofdeath (07.12.2020).

22. ZERKALOV D., TKACHUK K., 2011, Engineering ecology: problems, monitoring, management, The foundation, Kiev: 580 . 